\title{
Vulnerability of U.S. National Parks to Sea-Level Rise and Coastal Change
}

\section{Introduction}

The National Park Service (NPS) manages nearly 12,000 kilometers (7,500 miles) of shorelines along oceans and the Great Lakes. In 2001, the U.S. Geological Survey (USGS), in partnership with the NPS Geologic Resources Division, began conducting hazard assessments and creating map products (fig. 1) to assist the NPS in managing vulnerable coastal resources.

One of the most important and practical issues in coastal geology is determining the physical response of coastal environments to water-level changes. Two trends may affect shorelines in U.S. national parks: rising global sea level and falling Great Lakes water levels.

Global sea level has risen about 18 centimeters (7.1 inches) in the past century (Douglas, 1997). Computer models suggest that climate change will cause an additional rise of $48 \mathrm{~cm}$ (18.9 in.) by the year 2100 (Intergovernmental Panel on Climate Change, 2001), which is more than double the rate of sea-level rise over the past century. Thus, sealevel rise is expected to have a large, sustained impact on future coastal evolution. Potential effects include coastal erosion, saltwater intrusion into groundwater aquifers, inundation of wetlands and estuaries, and threats to cultural and historic resources, as well as park infrastructure.

Water levels in the Great Lakes have fluctuated over the past century by as much as 1.9 meters (6.2 feet). Changing climate is predicted to cause lake levels to decline by as much as $2.4 \mathrm{~m}(7.9 \mathrm{ft})$ over the next century (Great Lakes Regional Assessment Group, 2000). Potential effects include reducing areas accessible to cargo and recreational boats, exposing toxic sediments, and declining production of plankton that support fish.

\section{Variables Affecting Coastal Vulnerability}

Predicting future coastal evolution and vulnerability to change is difficult because many factors are involved. The USGS is implementing a classification of the relative vulnerability of different U.S. coastal environments to future sealevel rise (see Hammar-Klose and Thieler, 2001) and water-level changes in the Great Lakes. For coastal regions, the vulnerability classification is based on the relative contributions and interactions of six variables:

\section{Tidal range, which contributes to} inundation hazards

2. Wave height, which is linked to inundation hazards

3. Coastal slope (steepness or flatness of the coastal region), which is linked to the susceptibility of a coast to inundation by flooding and to the rapidity of shoreline retreat or advance

4. Historic shoreline change rates, which indicate how fast a section of shoreline has been eroding or accreting

5. Geomorphology, which indicates the relative erodibility of a section of shoreline

6. Historical rates of relative sea-level change, which correspond to how the global (eustatic) sea-level rise and local vertical land motion, such as tectonic uplift or subsidence, have affected a section of shoreline

\section{The Vulnerability Index}

The USGS rating system classifies the data variables according to risk. A mathematical formula allows scientists to relate different types of data and to calculate an index value. This approach combines the coastal system's susceptibility to change with its natural ability to adapt to changing environmental conditions, yielding a quantitative measure of the park's vulnerability to the effects

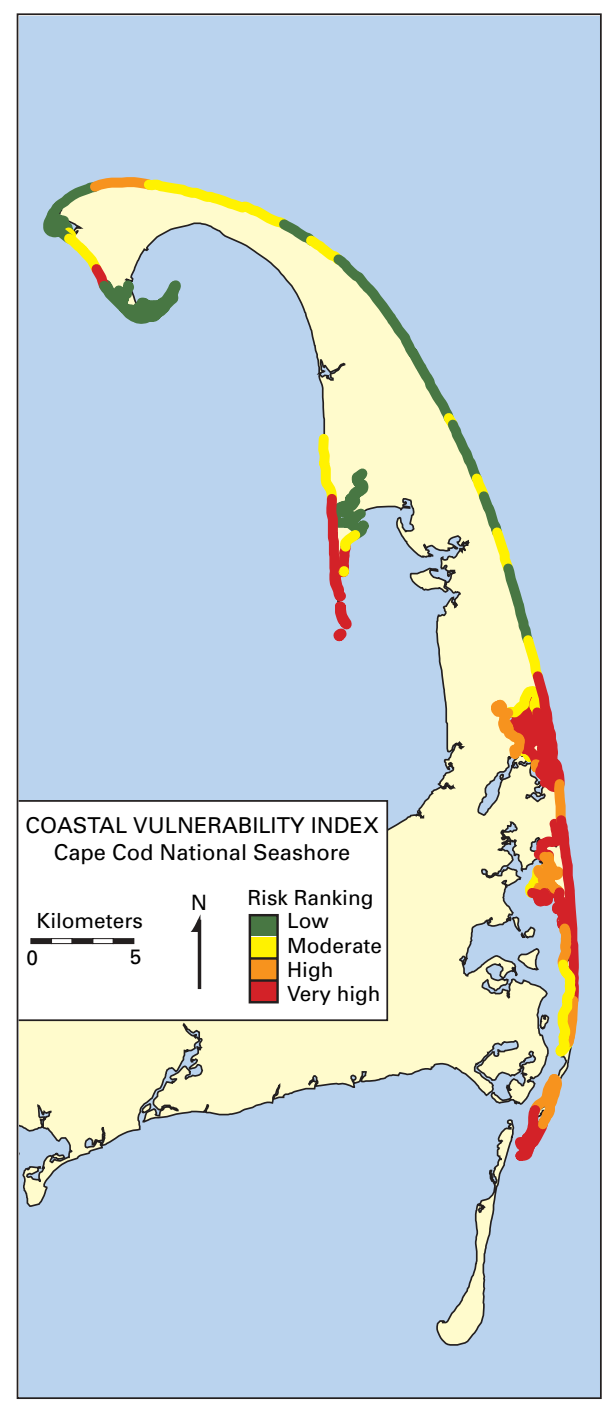

Figure 1. M ap of the coastal vulnerability index (CVI) for Cape Cod National Seashore in M assachusetts showing the relative vulnerability of the coast to changes in sea level. Areas along the coast are assigned a ranking from low to very high risk, based on the analysis of physical variables that contribute to coastal change.

of sea-level rise or changes in lake level. The coastal vulnerability index (CVI) value is a relative ranking of the likelihood that physical change will occur along the shoreline as sea level or lake level changes, and it serves as an objective tool for scientists and park managers. 


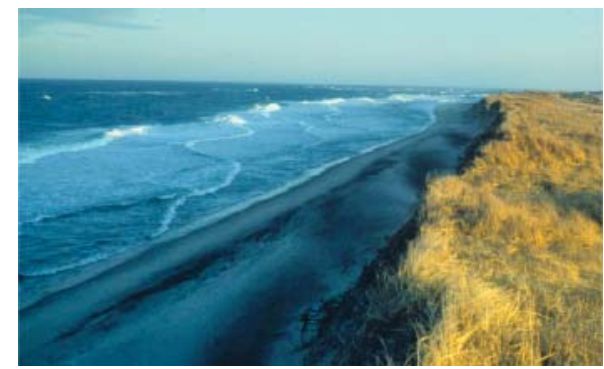

Figure 2. A narrow beach and eroded dunes result from a recent winter storm at Coast Guard Beach, Cape Cod National Seashore, Mass. Photograph courtesy of the National Park Service.

\section{Assessment of National Park System Units}

Pilot assessments have been completed for Cape Cod National Seashore in Massachusetts, Gulf Islands National Seashore in Mississippi and Florida, and Olympic National Park in Washington. Preliminary results from the USGS investigations show important differences in and among parks in terms of their vulnerability to coastal change due to future sea-level rise. For example, Cape Cod National Seashore has a variable coastal landscape consisting of high glacial bluffs, beaches, sand spits, and salt-marsh wetlands. The areas most vulnerable to sea-level rise (fig. 1) have the lowest regional coastal slopes, geomorphologic types that are susceptible to inundation, and the highest rates of shoreline change (fig. 2). Areas backed by glacial bluffs, comprising much of the coast, have a CVI indicating low risk. Conversely, Gulf Islands National Seashore has large areas of very high risk, because it is almost entirely a low-lying barrier-island system located on a low regional coastal slope (fig. 3).

Some park areas that are at the greatest risk are also culturally significant or very popular. In Gulf Islands National Seashore, Civil War-era Fort

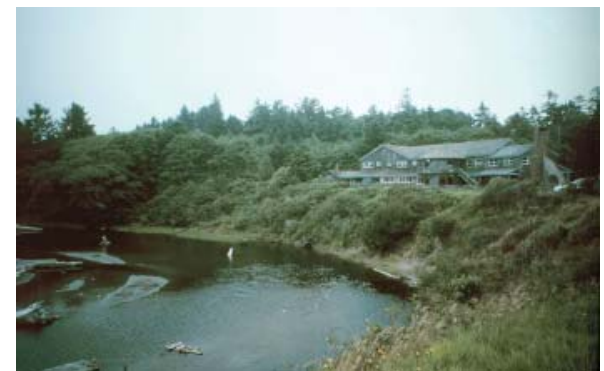

Figure 4. Kalaloch Lodge in Olympic National Park, Wash., is threatened by erosion. Longterm plans call for moving the lodge back from the cliff edge. Photograph by Erika HammarKlose, USGS.

Massachusetts is at great risk because of high rates of erosion, the low-sloping coastal plain, and the low-lying barrier island morphology. In contrast, most of Cape Cod National Seashore's infrastructure is located on high-elevation uplands away from the shore, and most high-visitor-use areas are accessible primarily by foot.

\section{National Park Service staff are} using the CVI data for long-term resource management plans, park facilities planning such as relocating coastal buildings or roads, and assessing longterm threats to cultural resources. For example, data from the Olympic National Park CVI study were used to identify vulnerable infrastructure and implement plans to relocate the Kalaloch Lodge (fig. 4). The data are also being integrated into the park's general management plan, the primary long-term planning document for the park. Future work for this cooperative project between the USGS and the NPS will map the coastal vulnerability index at additional parks throughout the United States and U.S. territories.

\section{References}

Douglas, B.C., 1997, Global sea rise; A redetermination: Surveys in Geophysics, v. 18, p. 279-292.
Great Lakes Regional Assessment Group, 2000, Preparing for a changing climate; The potential consequences of climate variability and change-Great Lakes overview (edited by P.J. Sousounis and J.M. Bisanz): Ann Arbor, MI, University of Michigan, $106 \mathrm{p}$.

Hammar-Klose, E.S., and Thieler, E.R., 2001, Coastal vulnerability to sealevel rise: A preliminary database for the U.S. Atlantic, Pacific, and Gulf of Mexico coasts: U.S. Geological Survey Digital Data Series DDS-68, one CD-ROM (Available online at http://pubs.usgs.gov/dds/dds68/)

Intergovernmental Panel on Climate Change, 2001, Climate change 2001; The scientific basis, contribution of Working Group I to the third assessment report of the Intergovernmental Panel on Climate Change: Cambridge, England, Cambridge University Press, 944 p. (Available online at http://www.ipcc.ch/)

\section{For additional information, please} contact:

E. Robert Thieler and

S. Jeffress Williams

U.S. Geological Survey

384 Woods Hole Road

Woods Hole, MA 02543-1598

E-mail: rthieler@usgs.gov jwilliams@usgs.gov

Telephone: 508-548-8700

Web: http://woodshole.er.usgs.gov/ project-pages/nps-cvi/

Rebecca Beavers

National Park Service

Natural Resource Program Center

Geologic Resources Division

P.O. Box 25287

Denver, CO 80225-0287

E-mail: Rebecca_Beavers@nps.gov

Telephone: 303-987-6945

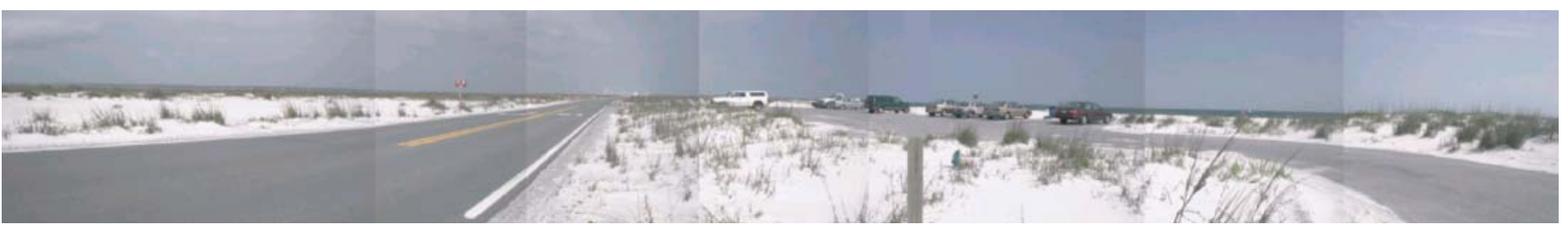

Figure 3. M ost of the Gulf Islands National Seashore, M iss. and Fla., is composed of low-lying barrier islands. In many locations, you can see from the ocean to the sound, as shown above. A combination of variables makes this seashore highly vulnerable to predicted sea-level rise. Photograph by Erika Hammar-Klose, USGS. 